\title{
Uptake and accumulation of di-n-butyl phthalate in six leafy vegetables under hydroponic conditions
}

\author{
Yong $\mathrm{Li}^{1,2}$, Huang-qian $\mathrm{Yan}^{1,2}$ and Xiang-yang $\mathrm{Yu}^{1,2^{*}}$
}

\begin{abstract}
The uptake and accumulation of di-n-butyl phthalate (DBP) in six leafy vegetables was investigated under hydroponic conditions. The test vegetables were six varieties of Brassica campestris ssp., including Kangresijiqing (KRSJQ), Xiadiqing (XDQ), Ziyoucai (ZYC), Aijiaohuang (AJH), Shanghaiqing (SHQ) and Gaogengbai (GGB). The root concentration factor (RCF), translocation factor (TF) and transpiration stream concentration factor (TSCF) were calculated in order to compare the difference of uptake and accumulation behaviours of DBP in vegetable varieties. The results showed that DBP was easily concentrated in vegetable roots, but was poorly translocated from the roots to the shoots. Among the six vegetables, the ability of concentrating DBP from the solution to shoots was the highest in GGB, followed by ZYC, KRSJQ, AJH, SHQ and XDQ. High concentrations of DBP (5.0 mg/L) seem to inhibit normal physiological activity in the vegetables, which resulted in a higher RCF and a lower TF and TSCF than in low-concentration treatment. The results will help to evaluate the safety of agricultural products and to provide evidence for screening DBP pollution-safe vegetable cultivars.
\end{abstract}

Keywords: Di-n-butyl phthalate, Root uptake, Root concentration factor, Translocation factor, Transpiration stream concentration factor

\section{Introduction}

Phthalic acid esters (PAEs) are widely used in industrial and household products, such as general plastic products, plastic films, toys, personal care products, food packaging and medical products (Stales et al. 1997; Wang et al. 2013; Zolfaghari et al. 2015; Pan et al. 2017). Widespread use of PAE-containing products has resulted in frequent PAE occurrence in water (Gao et al. 2014), soil (Xu et al. 2008), air (Bergh et al. 2011), food (Zhu et al. 2006; Nanni et al. 2011) and biota (Huang et al. 2008; Net et al. 2015). Therefore, extensive plastic and waste disposal make PAEs become problematic environmental contaminants. Generally, PAEs show toxicity and biological effects such as teratogenicity, carcinogenicity, and mutagenicity (Wang et al. 2015c; Li et al. 2016), and six PAEs are listed as

\footnotetext{
* Correspondence: yuxy@jaas.ac.cn

${ }^{1}$ Jiangsu Key Laboratory for Food Quality and Safety-State Key Laboratory Cultivation Base, Ministry of Science and Technology, 50 Zhongling Street, Nanjing 210014, China

${ }^{2}$ Institute of Food Safety and Nutrition, Jiangsu Academy of Agricultural Sciences, 50 Zhongling Street, Nanjing 210014, China
}

priority pollutants by the United States Environmental Protection Agency (U.S. EPA).

Di-n-butyl phthalate (DBP) is one of the most frequently identified PAEs in environmental samples (Vikelsøe et al. 2002; Shailaja et al. 2007). The present and distribution of DBP in the agricultural soils have been investigated. For example, the concentration of DBP ranged from 0.009 to $2.74 \mu \mathrm{g} / \mathrm{kg}$ in the agricultural soils from Haizhou district, Guangzhou, China (Zeng et al. 2008), from 0.099 to $8.54 \mu \mathrm{g} / \mathrm{kg}$ in agricultural soils with plastic film mulching from Shandong, China ( $\mathrm{Li}$ et al. 2016), and from 0.083 to $6.31 \mu \mathrm{g} / \mathrm{kg}$ in vegetable soils from suburbs of Xianyang, China (Wang et al. 2015b). Much research has reported that the DBP from plastics or PAE-contaminated soils could be taken up by plants and the concentration of DBP varied according to the variety of plants (Blaine et al. 2013). Wang et al. (2015a) has reported that $79.5 \%$ of vegetable samples exceeded maximum residue limits $(0.3 \mathrm{mg} / \mathrm{kg})$ in food. Some studies have demonstrated that DBP affects the growth of vegetables (Dueck et al. 2003; Liao et al.

(c) The Author(s). 2019 Open Access This article is distributed under the terms of the Creative Commons Attribution 4.0 International License (http://creativecommons.org/licenses/by/4.0/), which permits unrestricted use, distribution, and 
2009). Both DBP and its primary metabolite, mono-nbutyl phthalate (MBP), can be taken up and translocated in three common vegetables or fruit species (Sun et al. 2015). Lin et al. (2016) studied how DBP entered the roots of pumpkin seedlings and concluded that the uptake of DBP included a carrier-mediated and energydependent process that did not involve the participation of aquaporins. It is extremely important to research the absorption and translocation of DBP by plants (Yin et al. 2003; Cai et al. 2008; Cai et al. 2017), but investigations of the uptake and distribution of DBP in vegetable cultivars are scarce.

In this study, an absorption experiment under hydroponic conditions was carried out to investigate the uptake and translocation of di-n-butyl phthalate (DBP) by six leafy vegetables, including Kangresijiqing (KRSJQ), Xiadiqing (XDQ), Ziyoucai (ZYC), Aijiaohuang (AJH), Shanghaiqing (SHQ) and Gaogengbai (GGB). All of them are varieties of Brassica rapa. The vegetables were hydroponically exposed to DBP at 1.0 and $5.0 \mathrm{mg} / \mathrm{L}$ for $24 \mathrm{~h}$. The concentrations of DBP in solutions and plant tissues were analysed by Agilent gas chromatographymass spectrometer (GC/MS). The root concentration factor (RCF), translocation factor (TF) and transpiration stream concentration factor (TSCF) were applied to compare the differences in the uptake and translocation of DBP in vegetable varieties.

\section{Materials and methods}

\section{Reagents and materials}

The standard DBP was purchased from Sigma-Aldrich (St. Louis, MO, USA). Acetonitrile (HPLC grade) was purchased from Merck Company (Darmstadt, Germany). Graphitized carbon black (GCB), anhydrous magnesium sulfate $(\mathrm{MgSO} 4)$ and sodium chloride $(\mathrm{NaCl})$ were obtained from Shanghai Anpel Scientific Instrument Co., Ltd. (Shanghai, China). The stock solutions of DBP were prepared in acetonitrile and stored in amber bottles at $20^{\circ} \mathrm{C}$ before use.

\section{Experimental design}

The selected cultivars, namely, Kangresijiqing (KRSJQ), Xiadiqing (XDQ), Ziyoucai (ZYC), Aijiaohuang (AJH), Shanghaiqing (SHQ) and Gaogengbai (GGB), are widely grown in China and varieties of Brassica campestris ssp. the seeds of six vegetable cultivars were obtained from Jiangsu Agricultural Academy of Sciences (Nanjing, China). After being disinfected and activated, the seeds were germinated in wet paper towels for 2 days at $30^{\circ} \mathrm{C}$ and then transferred to nursery trays. When the vegetables grew to the 6-8 leaf stage, the plants were transferred to $0.5-\mathrm{L}$ amber containers filled with nutrient solution. Each vegetable was exposed to two levels of DBP added to the nutrient solution, which was modified from Hoagland's nutrient solution formula (Ge et al. 2016). The DBP concentrations were $1.0 \mathrm{mg} / \mathrm{L}$ and $5.0 \mathrm{mg} / \mathrm{L}$. Each level necessitated five containers, and each container contained 2 plants. In addition, two kinds of controls were prepared: one consisted of a group of containers that contained untreated plants but without DBP in the nutrient solution, to assess environmental pollution; and the other consisted of hydroponic solution controls supplemented with DBP but without plants, to assess the degradation of DBP in the solution during the experiment. The trial was carried out in a growth chamber. The chamber was set to $60 \%$ relative air humidity and an 8:00-22:00 light day-night cycle. The temperature inside the chamber was $25^{\circ} \mathrm{C}$ during the day and $18^{\circ} \mathrm{C}$ at night.

After $24 \mathrm{~h}$ of growth, vegetables were collected, after which their roots and shoots were separated. The shoots included stem and leaves, both of which were edible. The nutrient solution from the containers was collected, and the volume of the nutrient solution was measured to calculate the amount of transpiration. All samples were stored at $-20^{\circ} \mathrm{C}$ until analysis.

\section{Extraction, purification and analysis}

Five millilitres of nutrient solution were added to a 50$\mathrm{mL}$ glass centrifuge tube and then extracted with $10 \mathrm{~mL}$ of HPLC-grade $\mathrm{n}$-hexane. Then, the mixture was shaken using a rotary shaker for $1 \mathrm{~h}$. The samples were then placed for $1 \mathrm{~min}$ for separation. One millilitre of the supernatant was then filtered through a $0.22-\mu \mathrm{m}$ membrane into a sample vial for GC-MS analysis.

The samples of vegetable tissues and the soil were prepared according to the QuECHERS method. Two grams of homogenized plant samples was placed in a $50-\mathrm{mL}$ glass centrifuge tube, and $4 \mathrm{~mL}$ of HPLC-grade acetonitrile was added. The samples were then extracted in an ultrasonic water bath for $30 \mathrm{~min}$ at $30{ }^{\circ} \mathrm{C}$, after which $0.5 \mathrm{~g}$ of sodium chloride was added. Then, the samples were thoroughly mixed for $1 \mathrm{~min}$ using a vortex mixer. A 2-mL aliquot of the supernatant was transferred to a 10 - $\mathrm{mL}$ glass test tube containing both $50 \mathrm{mg}$ of anhydrous magnesium sulfate and $50 \mathrm{mg}$ of graphitized carbon black. The samples were then vortexed for $1 \mathrm{~min}$. In the end, $1 \mathrm{~mL}$ of supernatant was filtered through a $0.22-\mu \mathrm{m}$ membrane into a sample vial for GC-MS analysis.

All samples were analysed with an Agilent 6890 gas chromatograph coupled with an Agilent 5973 mass spectrometer (GC-MS). Gas chromatographic conditions were as follows: a DB-5 capillary column with the dimensions of $30 \mathrm{~m} \times 025 \mathrm{~mm} \times 0.25 \mu \mathrm{m}$ (Agilent, USA); high-purity $\mathrm{He}$ gas ( $\geq 99.999 \%$ ); a flow rate of $0.5 \mathrm{~mL} /$ $\mathrm{min}$; an oven temperature that started at $50^{\circ} \mathrm{C}$ for $1 \mathrm{~min}$, was maintained for $1 \mathrm{~min}$, increased to $250^{\circ} \mathrm{C}$ at a rate of $30^{\circ} \mathrm{C} \mathrm{min}{ }^{-1}$, and was maintained for another $5 \mathrm{~min}$; an inlet temperature of $250^{\circ} \mathrm{C}$; and an injection volume of 
$1 \mu \mathrm{L}$, in splitless mode. Mass spectrometry conditions were as follows: an EI source temperature of $250^{\circ} \mathrm{C}$; a quadrupole temperature of $150^{\circ} \mathrm{C}$; an ionization energy of $70 \mathrm{eV}$; and a transfer line temperature of $280{ }^{\circ} \mathrm{C}$. The analysis was performed in selected ion monitoring (SIM) mode. The primary characteristic $m / z$ of DBP was 149, 206 and 91, where the $m / z$ of 149 was used for quantification.

\section{Quality control/quality assurance}

All analytical procedures were monitored with strict quality assurance and quality control measures using the procedure reported by $\mathrm{Wu}$ et al. (2018). The method blanks were run with every extraction and cleanup procedures without nutrient solution and plant tissue samples. Only a very small concentration of DBP was found in the procedural blanks which was at much lower concentrations (generally $<5 \%$ ) than those in the PAEtreated samples. The average concentrations of DBP in procedural blanks were appropriately subtracted from those in the corresponding sample extracts. Qualitative analysis of DBP was based on matching the retention time with the standard solutions and characteristic ions. Quantitative analysis was performed by using the external calibration method based on a five-point calibration curve, where the calibration concentration ranged from 0 to $5.0 \mathrm{mg} / \mathrm{L}$. Besides, average recoveries and relative standard deviations (RSDs) of DBP in different matrices were obtained to evaluate the method performance by analysing the three replicates of the supplemented samples at three different supplementation levels that were between 1 and $5.0 \mathrm{mg} / \mathrm{L}$. The average recoveries of DBP were in the range of $76.5 \sim 88.0 \%$, and the RSDs were in the range of $3.01 \sim 7.07 \%$. The linearity was strong and ranged from $0.005 \sim 5 \mathrm{mg} / \mathrm{L}$ with $\mathrm{R}^{2}>0.999$. The limit of detection (LOD) and limit of quantification (LOQ) were 0.004 and $0.01 \mathrm{mg} / \mathrm{L}$, respectively.

\section{Statistical treatment of data}

The root concentration factor ( $\mathrm{RCF}$ ) indicates the tendency of plant roots to take up compounds from the medium and was defined as the ratio of the DBP concentration in roots to the DBP concentration in solutions (Kraaij and Connell 1997):

$$
\mathrm{RCF}=\mathrm{C}_{\text {root }} / \mathrm{C}_{\text {solution }}
$$

The translocation factor (TF) was introduced to assess the capability of plants to translocate organic chemicals from roots to other parts (Ge et al. 2015):

$$
\mathrm{TF}=\mathrm{C}_{\text {shoot }} / \mathrm{C}_{\text {root }}
$$

The transpiration stream concentration factor (TSCF) was estimated by dividing the amount of the DBP in the foliage by the DBP concentration in the nutrient solution multiplied by the volume of water transpired by the plant (Trapp 2000):

$$
\mathrm{TSCF}=\frac{\mathrm{C}_{\text {shoot }} * \mathrm{M}_{\text {shoot }}}{\mathrm{C}_{\text {solution }} * \mathrm{~V}_{\text {water }}}
$$

where $C_{\text {shoot }}$ is the DBP concentration $(\mathrm{mg} / \mathrm{kg})$ in the vegetable shoot after exposure; $M_{\text {shoot }}$ is the root dry weight $(\mathrm{kg})$ of the vegetable shoot; $\mathrm{V}_{\text {water }}$ is the transpired volume of water $(\mathrm{L})$; and $\mathrm{C}_{\text {solution }}$ is the DBP concentration $(\mathrm{mg} / \mathrm{L})$ in solution.

Besides, the independent sample T-test was used to compare differences of the uptake and accumulation of DBP in vegetable varieties.

\section{Results and discussion}

DBP concentration in solutions and vegetable tissues

In this study, six vegetables were exposed to the solutions with DBP at 1.0 and $5.0 \mathrm{mg} / \mathrm{L}$. The initial concentrations of $\mathrm{DBP}$ in the solutions ranged from 0.57 to $0.73 \mathrm{mg} / \mathrm{L}$ for the $1.0 \mathrm{mg} / \mathrm{L}$ treatment and from 3.17 to $4.36 \mathrm{mg} / \mathrm{L}$ for the $5.0 \mathrm{mg} / \mathrm{L}$ treatment (Table 1). After $24 \mathrm{~h}$ of exposure, the concentrations of DBP in the solutions of the blank control ranged from 0.18 to $0.27 \mathrm{mg} / \mathrm{L}$ for the $1.0 \mathrm{mg} / \mathrm{L}$ treatment and from 1.80 to $2.25 \mathrm{mg} / \mathrm{L}$ for $5.0 \mathrm{mg} / \mathrm{L}$ treatment (Table 1). As can be seen, there is approximately 30 to $40 \%$ of DBP missing in the solution of the blank control by comparison with the initial concentration of DBP. This may indicate that a portion of DBP in the nutrient solutions degraded during $24 \mathrm{~h}$ of

Table 1 DBP concentrations in the nutrient solution for six vegetables (Kangresijiqing (KRSJQ), Xiadiqing (XDQ), Ziyoucai $(\mathrm{ZYC})$, Aijiaohuang (AJH), Shanghaiqing (SHQ) and Gaogengbai $(\mathrm{GGB})$ ). Each treatment consisted of five replicates. The values with the different letter(s) were significantly different $(p<0.05)$

\begin{tabular}{lllll}
\hline Treatment & Variety & \multicolumn{3}{l}{ DBP concentration $(\mathrm{mg} / \mathrm{L})$ in solutions } \\
\cline { 3 - 5 } & & $\mathrm{C}_{0}{ }^{\mathrm{a}}$ & $\mathrm{C}_{1}{ }^{\mathrm{b}}$ & $\mathrm{C}_{2}{ }^{\mathrm{c}}$ \\
\hline $1.0 \mathrm{mg} / \mathrm{L}$ & KRSJQ & $0.73 \pm 0.05 \mathrm{~d}$ & $0.27 \pm 0.01 \mathrm{e}$ & $0.21 \pm 0.01 \mathrm{f}$ \\
& XDQ & $0.73 \pm 0.05 \mathrm{~d}$ & $0.27 \pm 0.01 \mathrm{e}$ & $0.25 \pm 0.02 \mathrm{f}$ \\
& ZYC & $0.73 \pm 0.05 \mathrm{~d}$ & $0.27 \pm 0.01 \mathrm{e}$ & $0.28 \pm 0.03 \mathrm{f}$ \\
& AJH & $0.64 \pm 0.00 \mathrm{~d}$ & $0.25 \pm 0.01 \mathrm{e}$ & $0.18 \pm 0.02 \mathrm{f}$ \\
& SHQ & $0.64 \pm 0.00 \mathrm{~d}$ & $0.25 \pm 0.01 \mathrm{e}$ & $0.21 \pm 0.03 \mathrm{f}$ \\
& GGB & $0.57 \pm 0.00 \mathrm{~d}$ & $0.18 \pm 0.01 \mathrm{e}$ & $0.16 \pm 0.02 \mathrm{f}$ \\
& KRSJ & $4.36 \pm 0.11 \mathrm{~d}$ & $2.25 \pm 0.07 \mathrm{e}$ & $1.82 \pm 0.23 \mathrm{f}$ \\
& XDQ & $4.36 \pm 0.11 \mathrm{~d}$ & $2.25 \pm 0.07 \mathrm{e}$ & $1.76 \pm 0.13 \mathrm{f}$ \\
& ZYC & $4.36 \pm 0.11 \mathrm{~d}$ & $2.25 \pm 0.07 \mathrm{e}$ & $1.97 \pm 0.11 \mathrm{f}$ \\
& AJH & $3.67 \pm 0.15 \mathrm{~d}$ & $2.03 \pm 0.01 \mathrm{e}$ & $1.39 \pm 0.09 \mathrm{f}$ \\
& SHQ & $3.67 \pm 0.15 \mathrm{~d}$ & $2.03 \pm 0.01 \mathrm{e}$ & $1.56 \pm 0.16 \mathrm{f}$ \\
& GGB & $3.17 \pm 0.04 \mathrm{~d}$ & $1.80 \pm 0.05 \mathrm{e}$ & $1.33 \pm 0.05 \mathrm{f}$ \\
\hline
\end{tabular}

${ }^{a}$ DBP concentration in the solution before exposure

${ }^{b}$ DBP concentration in the solutions without vegetables

${ }^{\mathrm{C}} \mathrm{DBP}$ concentration in the solutions containing vegetables 
exposure. It has been reported that DBP has fast degradation half-lives in surface and marine waters, ranging from 1 day to 2 weeks (Gao et al. 2014). Moreover, the nutrient solutions were acidic, which can accelerate the degradation of DBP (Stales et al. 1997). After exposure, the DBP concentrations in the solutions containing vegetables ranged from 0.16 to $0.28 \mathrm{mg} / \mathrm{L}$ for the $1.0 \mathrm{mg} / \mathrm{L}$ treatment and from 1.33 to $1.97 \mathrm{mg} / \mathrm{L}$ for $5.0 \mathrm{mg} / \mathrm{L}$ treatment (Table 1), which were much lower than in the solutions of the blank control $(P<0.05)$. This is likely due to the uptake of DBP by the test vegetables from the solution.

To investigate the uptake and translocation behaviour of DBP in vegetables, the roots and shoots of individual vegetables were separated and analysed. The DBP concentrations of the shoots and roots of different vegetables are shown in Table 2. As shown in Table 2, DBP was detected in both roots and shoots, which indicates that DBP in solutions could be taken up by the roots of vegetables and translocated to shoots. However, the concentration of DBP varied with vegetable variety and tissue. For the $1.0 \mathrm{mg} / \mathrm{L}$ treatment, the concentrations of $\mathrm{DBP}$ in the roots of KRSJ, XDQ, ZYC, AJH, SHQ and GGB were 29.20, 12.76, 20.45, 13.48, 24.69 and 43.62 $\mathrm{mg} / \mathrm{kg}$, respectively. GGB had the highest DBP concentrations in the roots, followed by KRSJQ, SHQ, ZYC, $\mathrm{XDQ}$ and $\mathrm{AJH}$. The DBP concentrations in the shoots ranged from $0.07 \mathrm{mg} / \mathrm{kg}$ (XDQ) to $0.23 \mathrm{mg} / \mathrm{kg}$ (GGB). Among six vegetables, the shoots of GGB, ZYC, KRSJQ have a higher concentration of DBP than those of the other three vegetables $(P<0.05)$. For individual vegetables, the DBP concentration in roots was far higher than in shoots $(P<0.05)$, which shows that most DBP was concentrated in the vegetable roots and less DBP was transported into vegetable shoots. For the $5.0 \mathrm{mg} / \mathrm{L}$ treatment, the concentration of DBP ranged from $150.78 \mathrm{mg} / \mathrm{kg}$ (AJH) to $421.69 \mathrm{mg} / \mathrm{kg}$ (GGB). The concentration of DBP in the shoots of KRSJQ, XDQ, ZYC, AJH, SHQ and GGB

Table 2 DBP concentrations in nutrient solution and vegetable tissues (Kangresijiqing (KRSJQ), Xiadiqing (XDQ), Ziyoucai (ZYC), Aijiaohuang (AJH), Shanghaiqing (SHQ) and Gaogengbai (GGB)) after 24-h exposure. Each treatment consisted of five replicates. The values with the different letter(s) were significantly different $(p<0.05)$

\begin{tabular}{llllll}
\hline Variety & \multicolumn{2}{l}{$1.0 \mathrm{mg} / \mathrm{L}$ treatment } & & $5.0 \mathrm{mg} / \mathrm{L}$ treatment \\
\cline { 2 - 3 } \cline { 5 - 6 } & Root $(\mathrm{mg} / \mathrm{kg})$ & Shoot $(\mathrm{mg} / \mathrm{kg})$ & & Root $(\mathrm{mg} / \mathrm{kg})$ & Shoot $(\mathrm{mg} / \mathrm{kg})$ \\
\hline KRSJQ & $29.20 \pm 1.68 \mathrm{a}$ & $0.12 \pm 0.01 \mathrm{~b}$ & & $301.71 \pm 20.85 \mathrm{a}$ & $0.31 \pm 0.02 \mathrm{~b}$ \\
XDQ & $12.76 \pm 1.85 \mathrm{a}$ & $0.07 \pm 0.01 \mathrm{~b}$ & & $173.10 \pm 12.78 \mathrm{a}$ & $0.16 \pm 0.02 \mathrm{~b}$ \\
ZYC & $20.45 \pm 1.71 \mathrm{a}$ & $0.13 \pm 0.02 \mathrm{~b}$ & & $257.81 \pm 24.29 \mathrm{a}$ & $0.33 \pm 0.05 \mathrm{~b}$ \\
AJH & $13.48 \pm 2.55 \mathrm{a}$ & $0.08 \pm 0.01 \mathrm{~b}$ & & $150.78 \pm 19.19 \mathrm{a}$ & $0.30 \pm 0.02 \mathrm{~b}$ \\
SHQ & $24.69 \pm 0.95 \mathrm{a}$ & $0.09 \pm 0.01 \mathrm{~b}$ & & $249.70 \pm 19.66 \mathrm{a}$ & $0.29 \pm 0.03 \mathrm{~b}$ \\
GGB & $43.62 \pm 4.28 \mathrm{a}$ & $0.23 \pm 0.03 \mathrm{~b}$ & & $421.69 \pm 22.76 \mathrm{a}$ & $0.52 \pm 0.03 \mathrm{~b}$ \\
\hline
\end{tabular}

were $0.31,0.16,0.33,0.30,0.29$ and $0.52 \mathrm{mg} / \mathrm{kg}$, respectively. The shoot of GGB has the highest concentration of DBP; however, XDQ was just the opposite. By comparing the two treatments, the concentrations of DBP in the vegetable shoots and roots increased with increasing DBP concentrations in the solutions.

\section{Root concentration factor, translocation factor and transpiration stream concentration factor}

For deeply comparing the difference in the uptake and translocation of DBP in six vegetables, the root concentration factor (RCF), translocation factor (TF) and transpiration stream concentration factor (TSCF) were computed (Blaine et al. 2013). In general, the RCF of a compound is related its partition coefficient in octanol/water $\left(\mathrm{K}_{\mathrm{ow}}\right)$ and its solubility in water (Trapp 2000). The RCFs of the six vegetables in different treatments are shown in Fig. 1. In the $1.0 \mathrm{mg} / \mathrm{L}$ treatment, the RCFs of KRSJQ, XDQ, ZYC, $\mathrm{AJH}, \mathrm{SHQ}$ and GGB were 138, 52, 75, 73, 121 and 271, respectively. All RCFs were far larger than one, which indicates that $\mathrm{DBP}$ was easily concentrated in vegetable roots from the solutions. GGB had the highest RCF value, followed by KDQ, SHQ, ZYC, AJH and XDQ. This indicates that GGB has the greatest ability to concentrate DBP in its roots from the solutions; however, XDQ had the weakest ability. The difference may be attributed to the properties of the vegetables, such as root lipid content, transpiration volume and the length of the root (Wu et al. 2013). For the $5.0 \mathrm{mg} / \mathrm{L}$ treatment, the RCFs of the six vegetables ranged from 109 to 317 . GGB had the highest RCF value, followed by KRSJQ, SHQ, ZYC, AJH and $\mathrm{XDQ}$. Moreover, the RCFs for individual vegetables in the $5.0 \mathrm{mg} / \mathrm{L}$ treatment were higher than in the $1.0 \mathrm{mg} / \mathrm{L}$ treatment $(P<0.05)$, which seems to indicate that the vegetable has a higher ability to concentrate DBP in roots in high-level treatment.

The TFs of the six vegetables in the different treatments are shown in Fig. 2. In the $1.0 \mathrm{mg} / \mathrm{L}$ treatment, the TF values of the six vegetables ranged from 0.004 to 0.007. All the DBP TFs were far smaller than one, which indicates a poor capacity of the tested vegetables to translocate DBP from the roots to the shoots. The $\mathrm{K}_{\text {ow }}$ of DBP is equal to 4.5 , which indicates that DBP can enter the root tissue but cannot enter the xylem for translocation from roots to aboveground parts (Burken and Schnoor 1998). Among the six vegetables, ZYC had the highest $\mathrm{TF}$ value, followed by $\mathrm{AJH}, \mathrm{XDQ}, \mathrm{GGB}$, SHQ and KRSJQ. This indicates that ZYC has the greatest ability to translocate DBP from the roots to the shoots. The difference of DBP translocation in six vegetables from the roots to shoots should be due to the vegetable properties (Dueck et al. 2003; Liao et al. 2009). For the $5.0 \mathrm{mg} / \mathrm{L}$ treatment, the TF values of the six vegetables ranged from 0.001 to 0.002 . It can be seen that 


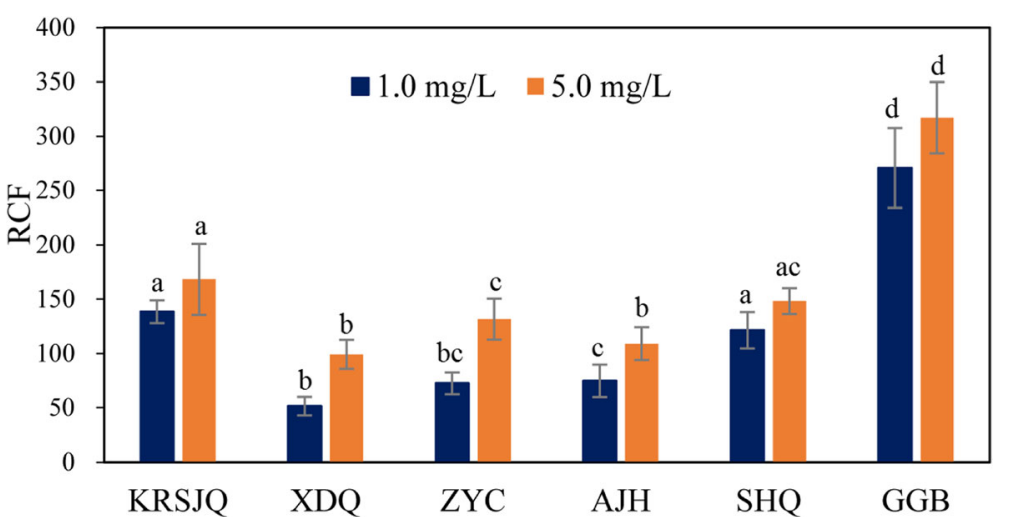

Fig. 1 The root concentration factor (RCF) for six vegetables (Kangresijiqing (KRSJQ), Xiadiqing (XDQ), Ziyoucai (ZYC), Aijiaohuang (AJH), Shanghaiqing (SHQ) and Gaogengbai (GGB)) in $1.0 \mathrm{mg} / \mathrm{L}$ and $5.0 \mathrm{mg} / \mathrm{L}$ treatments. Each treatment consisted of five replicates. The bars with the different letter(s) were significantly different $(p<0.05)$

the TFs in the $5.0 \mathrm{mg} / \mathrm{L}$ treatment were significantly lower than those in the $1.0 \mathrm{mg} / \mathrm{L}$ treatment.

The transpiration stream concentration factor (TSCF) indicates how readily compounds are taken up and translocated by a plant (Zhang et al. 2009). When the TSCF is less than one, the compound in solution moves from the solution to the shoots more slowly than water does. A TSCF value larger than one indicates that the compound in solution moves from the solution to shoots faster than water. Figure 3 shows the TSCF values of the different vegetables in different treatments. In the $1.0 \mathrm{mg} / \mathrm{L}$ treatment, the TSCFs of KRSJQ, XDQ, ZYC, AJH, SHQ and GGB were 0.17, 0.09, 0.18, 0.11, 0.10 and 0.28 , respectively. All TSCF values were less than one, which indicates that the DBP in solution moves from the solution to the shoots more slowly than water. This results in poor translocation of DBP from the solution to shoots. Among the six vegetables, GGB had the highest TSCF, followed by ZYC, KRSJQ, AJH, SHQ and XDQ. This indicates that XDQ had the weakest ability to accumulate DBP from solutions into shoots, while GGB had the greatest ability. For the $5.0 \mathrm{mg} / \mathrm{L}$ treatment, the TSCF values of KRSJQ, XDQ, ZYC, AJH, SHQ and GGB were 0.05, 0.04, 0.07, 0.05, 0.04 and 0.09, respectively. GGB has the highest TSCF value. For individual vegetables, the TSCF value in the $5.0 \mathrm{mg} / \mathrm{L}$ treatment was much smaller than in $1.0 \mathrm{mg} / \mathrm{L}$ treatment.

In the present study, DBP was easily concentrated in vegetable roots but was poorly translocated from the roots to the shoots. It seems to indicate that for the vegetables grown in DBP- contaminated soils, there is a higher residual risk of DBP in vegetable roots than in shoots ( $\mathrm{Lu}$ et al. 2018). Besides, the uptake and translocation behaviour of DBP in vegetable was related to its physicochemical property, such as the octanol/water partition coefficient $\left(\log K_{o w}\right)$. It has been reported that the organic compounds with $\log K_{o w}$ between -1 and 5 were considered mobile in the transpiration stream, however, the compounds with larger $\log K_{o w}$ values was more easily accumulated in plant roots (Bromilow et al.

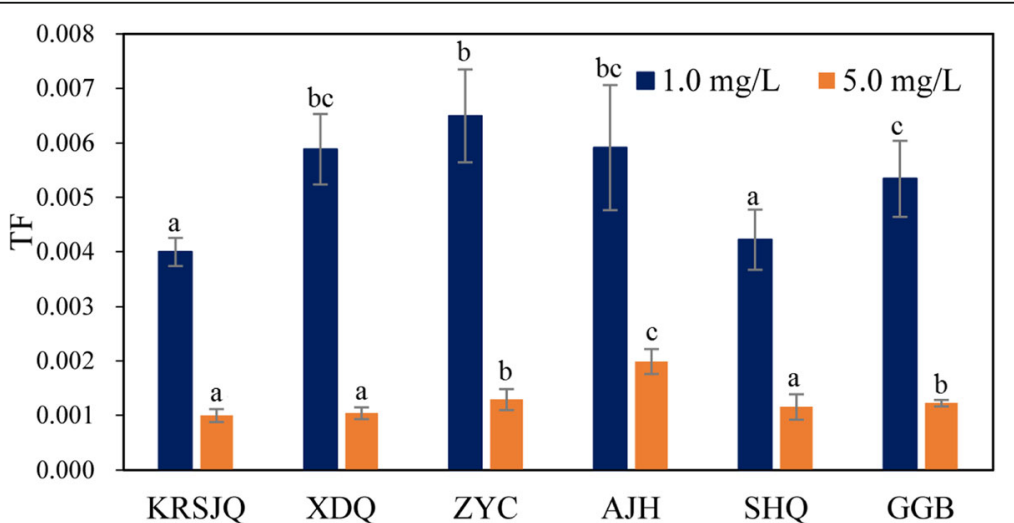

Fig. 2 The translocation factor (TF) for six vegetables (Kangresijiqing (KRSJQ), Xiadiqing (XDQ), Ziyoucai (ZYC), Aijiaohuang (AJH), Shanghaiqing $(\mathrm{SHQ})$ and Gaogengbai (GGB)) in $1.0 \mathrm{mg} / \mathrm{L}$ and $5.0 \mathrm{mg} / \mathrm{L}$ treatments. Each treatment consisted of five replicates. The bars with the different letter(s) were significantly different $(p<0.05)$ 


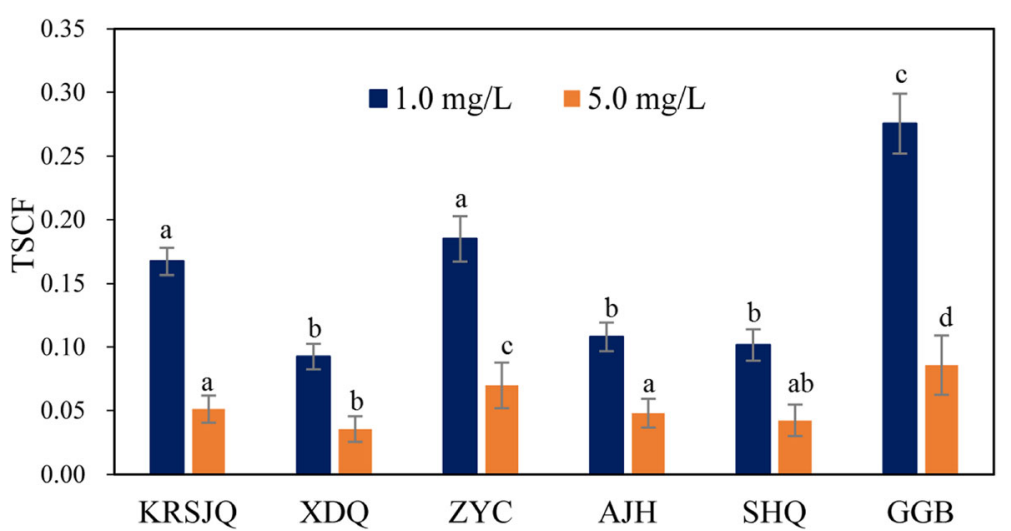

Fig. 3 The transpiration stream concentration factor (TSCF) for six vegetables (Kangresijiqing (KRSJQ), Xiadiqing (XDQ), Ziyoucai (ZYC), Aijiaohuang $(\mathrm{AJH})$, Shanghaiqing $(\mathrm{SHQ})$ and Gaogengbai $(\mathrm{GGB}))$ in $1.0 \mathrm{mg} / \mathrm{L}$ and $5.0 \mathrm{mg} / \mathrm{L}$ treatments. Each treatment consisted of five replicates. The bars with the different letter $(s)$ were significantly different $(p<0.05)$

1990). In this study, the measured RCF in vegetable roots ranged from 52 to 307 was smaller than in pumpkin (Cucurbita moschata) seedlings (RCF nearly 2000) (Lin et al. 2017); however, the measured RCF was quite larger than in Ipomoea aquatica $(\mathrm{RCF}<1)$ and in edible plants (RCF ranged from 0.16 to 4.78) growing in DBPcontaminated soils (Cai et al. 2008; Sun et al. 2015). The TF in this study was much smaller than in Ipomoea aquatica grown in DBP-treated soils (ranged from 0.28 to 16.9) (Cai et al. 2008). The differences are likely due to the different initial concentrations of DBP, plant species, exposure time, and cultural conditions (Wu et al. 2013).

\section{Conclusion}

In this study, the uptake and translocation of di-n-butyl phthalate (DBP) by six vegetables was investigated under hydroponic conditions. The data of the root concentration factor (RCF), translocation factor (TF) and transpiration stream concentration factor (TSCF) show that DBP was easily concentrated in the vegetable roots but poorly translocated from the roots to the shoots. Among the six vegetables, GGB had the highest ability to concentrate DBP in its roots; however, ZYC had the greatest ability to translocate DBP from the roots to the shoots. In addition, high concentrations of DBP may cause the inhibition of normal physiological activity of the vegetables and resulted in a higher RCF, a lower TF and a lower TSCF of individual vegetables. The results will help to evaluate agricultural product safety and provide evidence for screening DBP pollution-safe vegetable cultivars. Further research is still needed to evaluate the occurrence of DBP in plants under field conditions.

\section{Abbreviations}

AJH: Aijiaohuang; DBP: Di-n-butyl phthalate; GC-MS: Gas ChromatographyMass Spectrometer; GGB: Gaogengbai; KRSJQ: Kangresijiqing; LOD: Limit of detection; LOQ: Limit of quantification; $\mathrm{MgSO}_{4}$ : Anhydrous magnesium sulfate; NaCl: Sodium chloride; PAEs: Phthalic acid esters; RCF: Root concentration factor; SHQ: Shanghaiqing; SIM: Selected ion monitoring; TF: Translocation factor; TSCF: Transpiration stream concentration factor; XDQ: Xiadiqing; ZYC: Ziyoucai

\section{Acknowledgements}

Not applicable

\section{Authors' contributions}

YL was involved in data acquisition, draft and critical revision of article, and final approval; and HY was involved in data acquisition and data analysis; XY was involved in the conception and design of the study, data analysis, draft and critical revision of article, and final approval. All authors read and approved the final manuscript.

\section{Authors' information}

Yong Li, Doctor, works at the research on ecological risk assessment of organic pollutants and agricultural product safety. Huangqian Yan, master, works at the research on ecological risk assessment of organic pollutants and agricultural product safety. Xiangyang Yu, professor, works at the research on ecological risk assessment of organic pollutants and agricultural product safety.

\section{Funding}

This work was supported by the Natural Science Foundation of Jiangsu Province, China (Grant No. BK20160576) and the Jiangsu Agricultural Science and Technology Innovation Fund, China (Grant No. CX(19)3006).

\section{Availability of data and materials}

All data supporting this article are included within the manuscript.

\section{Ethics approval and consent to participate}

Not applicable.

The manuscript has not been published before and is not currently being considered for publication elsewhere. We confirm that the manuscript has been read and approved by all named authors and that there are no other persons who satisfied the criteria for authorship but are not listed.

\section{Consent for publication}

The Author agrees to publication in the Journal.

Competing interests

The authors declare that they have no competing interest. 
Received: 15 April 2019 Accepted: 23 October 2019

Published online: 26 November 2019

\section{References}

Bergh, C., Torgrip, R., Emenius, G., \& Östman, C. (2011). Organophosphate and phthalate esters in air and settled dust - a multi-location indoor study. Indoor Air, 21, 67-76.

Blaine, A. C., Rich, C. D., Hundal, L. S., Lau, C., Mills, M. A., Harris, K. M., \& Higgins, C. P. (2013). Uptake of Perfluoroalkyl acids into edible crops via land applied biosolids: Field and greenhouse studies. Environmental Science \& Technology, 47, 14062-14069.

Bromilow, R. H., Chamberlain, K., \& Evans, A. A. (1990). Physicochemical aspects of phloem translocation of herbicides. Weed Science, 38, 305-314.

Burken, J. G., \& Schnoor, J. L. (1998). Predictive relationships for uptake of organic contaminants by hybrid poplar trees. Environmental Science \& Technology, 32, 3379-3385.

Cai, Q. Y., Mo, C. H., Zeng, Q. Y., Wu, Q. T., Férard, J. F., \& Antizar-Ladislao, B. (2008). Potential of Ipomoea aquatica cultivars in phytoremediation of soils contaminated with di- $\mathrm{n}$-butyl phthalate. Environmental \& Experimental Botany, 62, 205-211.

Cai, Q. Y., Xiao, P. Y., Zhao, H. M., Lü, H., Zeng, Q. Y., Li, Y. W., Li, H., Xiang, L., \& Mo, C. H. (2017). Variation in accumulation and translocation of di$\mathrm{n}$-butyl phthalate (DBP) among rice ( Oryza sativa L.) genotypes and selection of cultivars for low DBP exposure. Environmental Science \& Pollution Research, 24, 1-12.

Dueck, T. A., Van Dijk, C. J., David, F., Scholz, N., \& Vanwalleghem, F. (2003). Chronic effects of vapour phase di-n-butyl phthalate (DBP) on six plant species. Chemosphere, 53, 911-920.

Gao, D., Li, Z., Wen, Z., \& Ren, N. (2014). Occurrence and fate of phthalate esters in full-scale domestic wastewater treatment plants and their impact on receiving waters along the Songhua River in China. Chemosphere, 95, 24.

Ge, J., Lu, M., Wang, D., Zhang, Z., Liu, X., \& Yu, X. (2015). Dissipation and distribution of chlorpyrifos in selected vegetables through foliage and root uptake. Chemosphere, 144, 201-206.

Ge, J., Lu, M. X., Wang, D. L., Zhang, Z. Y., Liu, X. J., \& Yu, X. Y. (2016). Dissipation and distribution of chlorpyrifos in selected vegetables through foliage and root uptake. Chemosphere, 144, 201-206.

Huang, P. C., Tien, C. J., Sun, Y. M., Hsieh, C. Y., \& Lee, C. C. (2008). Occurrence of phthalates in sediment and biota: Relationship to aquatic factors and the biota-sediment accumulation factor. Chemosphere, 73, 539-544.

Kraaij, H., \& Connell, D. W. (1997). Bioconcentration and uptake kinetics of chlorobenzenes in soy-bean roots. Chemosphere, 34, 2607-2620.

Li, K., Ma, D., Wu, J., Chai, C., \& Shi, Y. (2016). Distribution of phthalate esters in agricultural soil with plastic film mulching in Shandong peninsula, East China. Chemosphere, 164, 314-321.

Liao, C. S., Yen, J. H., \& Wang, Y. S. (2009). Growth inhibition in Chinese cabbage ( Brassica rapa var. chinensis ) growth exposed to di- $\mathrm{n}$-butyl phthalate. Journal of Hazardous Materials, 163, 625-631.

Lin, Q., Chen, S., Chao, Y., Huang, X., Wang, S., \& Qiu, R. (2017). Carboxylesteraseinvolved metabolism of di-n-butyl phthalate in pumpkin (Cucurbita moschata) seedlings. Environmental Pollution, 220, 421-430.

Lin, Q., Yang, X., Huang, X., Wang, S., Chao, Y., \& Qiu, R. (2016). Subcellular distribution and uptake mechanism of di-n-butyl phthalate in roots of pumpkin (Cucurbita moschata) seedlings. Environmental Science and Pollution Research, 23, 329.

Lu, H. X., Mo, C. H., Zhao, H. M., Xiang, L., Katsoyiannis, A., Li, Y. W., Cai, Q. Y., \& Wong, M. H. (2018). Soil contamination and sources of phthalates and its health risk in China: A review. Environmental Research, 164, 417-429.

Nanni, N., Fiselier, K., Grob, K., Pasquale, M. D., Fabrizi, L., Aureli, P., \& Coni, E. (2011). Contamination of vegetable oils marketed in Italy by phthalic acid esters. Food Control, 22, 209-214.

Net, S., Sempéré, R., Delmont, A., Paluselli, A., \& Ouddane, B. (2015). Occurrence, fate, behavior and ecotoxicological state of phthalates in different environmental matrices. Environmental Science \& Technology, 49, 4019-4035.

Pan, Y., Wang, X., Yeung, L. W. Y., Sheng, N., Cui, Q., Cui, R., Zhang, H., \& Dai, J. (2017). Dietary exposure to di-isobutyl phthalate increases urinary 5-methyl2 '-deoxycytidine level and affects reproductive function in adult male mice. Journal of Environmental Sciences, 61, 14-23.

Shailaja, S., Ramakrishna, M., Mohan, S. V., \& Sarma, P. N. (2007). Biodegradation of di- $n$-butyl phthalate (DnBP) in bioaugmented bioslurry phase reactor. Bioresource Technology, 98, 1561-1566.
Stales, C. A., Peterson, D. R., Parkerton, T. F., \& Adams, W. J. (1997). The environmental fate of phthalate esters: A literature review. Chemosphere, 35, $667-749$

Sun, J., Wu, X., \& Gan, J. (2015). Uptake and metabolism of phthalate esters by edible plants. Environmental Science \& Technology, 49, 8471-8478.

Trapp, S. (2000). Modelling uptake into roots and subsequent translocation of neutral and ionisable organic compounds. Pest Management Science, 56, 767-778.

Vikelsøe, J., Thomsen, M., \& Carlsen, L. (2002). Phthalates and nonylphenols in profiles of differently dressed soils. Science of the Total Environment, $296,105-116$.

Wang, J., Chen, G., Christie, P., Zhang, M., Luo, Y., \& Teng, Y. (2015a). Occurrence and risk assessment of phthalate esters (PAEs) in vegetables and soils of suburban plastic film greenhouses. Science of the Total Environment, 523, 129-137.

Wang, J., Luo, Y., Teng, Y., Ma, W., Christie, P., \& Li, Z. (2013). Soil contamination by phthalate esters in Chinese intensive vegetable production systems with different modes of use of plastic film. Environmental Pollution, 180, 265-273.

Wang, L. J., Xu, X., \& Lu, X. W. (2015b). Phthalic acid esters (PAEs) in vegetable soil from the suburbs of Xianyang city, Northwest China. Environmental Earth Sciences, 74, 1487-1496.

Wang, X., Song, M., Guo, M., Chi, C., Mo, F., \& Shen, X. (2015c). Pollution levels and characteristics of phthalate esters in indoor air in hospitals. Journal of Environmental Sciences, 37, 67-74.

Wu, X., Ernst, F., Conkle, J. L., \& Gan, J. (2013). Comparative uptake and translocation of pharmaceutical and personal care products (PPCPs) by common vegetables. Environment International, 60, 15-22.

Wu, Y., Chen, X. X., Zhu, T. K., Li, X., Chen, X. H., Mo, C. H., Li, Y. W., Cai, Q. Y., \& Wong, M. H. (2018). Variation in accumulation, transport, and distribution of phthalic acid esters (PAEs) in soil columns grown with low- and high-PAE accumulating rice cultivars. Environmental Science and Pollution Research, 25, 17768-17780.

Xu, G., Li, F., \& Wang, Q. (2008). Occurrence and degradation characteristics of dibutyl phthalate (DBP) and di-(2-ethylhexyl) phthalate (DEHP) in typical agricultural soils of China. Science of the Total Environment, 393, 333-340.

Yin, R., Lin, X. G., Wang, S. G., \& Zhang, H. Y. (2003). Effect of DBP/DEHP in vegetable planted soil on the quality of capsicum fruit. Chemosphere, 50 , $801-805$

Zeng, F., Cui, K. Y., Xie, Z. Y., Wu, L. N., Liu, M., Sun, G. Q., Lin, Y. J., Luo, D. L., \& Zeng, Z. X. (2008). Phthalate esters (PAEs): Emerging organic contaminants in agricultural soils in peri-urban areas around Guangzhou, China. Environmental Pollution, 156, 425-434.

Zhang, H., Chen, J., Ni, Y., Zhang, Q., \& Zhao, L. (2009). Uptake by roots and translocation to shoots of polychlorinated dibenzo-p-dioxins and dibenzofurans in typical crop plants. Chemosphere, 76, 740-746.

Zhu, J., Phillips, S. P., Feng, Y. L., \& Yang, X. (2006). Phthalate esters in human milk: Concentration variations over a 6-month postpartum time. Environmental Science \& Technology, 40, 5276-5281.

Zolfaghari, M., Drogui, P., Seyhi, B., Brar, S. K., Buelna, G., Dubé, R., \& Klai, N. (2015). Investigation on removal pathways of Di 2-ethyl hexyl phthalate from synthetic municipal wastewater using a submerged membrane bioreactor. Journal of Environmental Sciences, 37, 37-50.

\section{Publisher's Note}

Springer Nature remains neutral with regard to jurisdictional claims in published maps and institutional affiliations.

Ready to submit your research? Choose BMC and benefit from:

- fast, convenient online submission

- thorough peer review by experienced researchers in your field

- rapid publication on acceptance

- support for research data, including large and complex data types

- gold Open Access which fosters wider collaboration and increased citations

- maximum visibility for your research: over $100 \mathrm{M}$ website views per year

At $\mathrm{BMC}$, research is always in progress.

Learn more biomedcentral.com/submission 